\begin{tabular}{|c|c|c|}
\hline & Int.J.Curr.Microbiol.App.Sci (2016) 5(12): 819-834 & \\
\hline & International Journal of Current Microbiology and Applied Sciences & \\
\hline & ISSN: 2319-7706 Volume 5 Number 12 (2016) pp. 819-834 & \\
\hline EXCELLENT & Journal homepage: http://www.ijcmas.com & \\
\hline PUBLISHERS & & www.jicmas.com \\
\hline
\end{tabular}

Original Research Article

http://dx.doi.org/10.20546/ijcmas.2016.512.091

\title{
Comparative Effect of Ozone and Traditional Antimycotic Drugs on the Growth of Some Fungal Causes of Recurrent Mastitis in Egyptian Buffaloes
}

\author{
Hassan A. Atef ${ }^{1}$, Nahed, M. El-Mokhtar ${ }^{1}$ and Hanaa M. Abdel Khalek ${ }^{2}$ \\ ${ }^{1}$ Department of Mycology and Mycotoxins, Animal Health Research Institute, \\ Agriculture Research Centre, Cairo, Egypt \\ ${ }^{2}$ Buffaloes Diseases Research Department, Animal Health Research Institute, \\ Agriculture Research Centre, Cairo, Egypt \\ *Corresponding author
}

\section{Keywords}

Ozone fumigation, Exposure time, Mastitis, Fungi, SEM, Buffaloes, Antifungal.

\section{Article Info}

Accepted: 28 November 2016 Available Online: 10 December 2016

\section{A B S T R A C T}

The antifungal potential of ozone fumigation was evaluated for growth inhibition of isolated fungi from recurrent mastitis in dairy buffaloes in comparison with some traditional chemical antifungal. One hundred samples were collected from private farm of dairy buffaloes suffering from repeated mastitis affection ( 20 samples of each of litters, swabs of workers hands and rations) and 40 mastitic milk samples from diseased mastitis animals. The predominant fungal isolates that recovered from samples were subjected for ozone fumigation. The effectiveness of ozone treatments on spore germination depended on ozone concentration and treatment duration. The gradual increase in ozone concentration induced progressive retardation of the spore viability and the required time for ozone exposure was decreased. Where, the growth inhibition of mould as A.flavus required exposure to $20 \mathrm{ppm}$ of ozone for 20 minutes ; to 40 ppm for 15 minutes and exposure to $60 \mathrm{ppm}$ of ozone for 10 minutes to be completely inhibited the fungal growth and no mycelia was observed. The ozone exposure of mould at different concentrations for time under 10 minutes not able to inhibit completely their growth and the inhibition was more pronounced with the extension of exposure time. On the other hand, the growth inhibition of yeast was more sensitive for ozone fumigation which required fewer time of exposure (5-10 $\mathrm{min})$. When the treated fungi with ozone fumigation were subjected to scanning by electron microscopy (SEM),showed many destructive changes in morphology and loss of cell integrity and hence its viability and function were inhibited. When ozone concentrations and time of exposure increased, a serious and destructive changes to fungal structure would occur. The field application on selected highly contaminated commercial animal ration with different moulds, evidenced also higher potential antifungal effects of the ozone fumigation. Where, all used concentrations of ozone (20, $40 \& 60 \mathrm{ppm})$ were effective in decontamination when contaminated rations exposed for 20 minutes and more. Therefore, fumigation with ozone gas can be used as a good method for achieving sanitation and decreasing initial microbial load in rations facilities and spoilage on a long term. Otherwise, the animal diseases could be prevented when healthy feed, disinfect storage, processing areas and other utensils which significantly reflected in improving animal health. 


\section{Introduction}

Feeds beside other environmental factors suspected to play important role in animal infections. The dangers of mould and yeast besides causing animal mycosis, they produced fungal metabolites such as mycotoxins, such mycotoxins produced under adverse effect of environmental conditions. These mycotoxins residues in food and feed causes carcinogenic, teratogen, hemorrhagic and immunosuppression effect to human and animal health (Sayed El Ahl et al., 2006 and Hassan et al., 2007).

In spite of progressive advances in harvesting, storage and processing technologies, fungal spoilage still has a major economic impact on world food supplies. The most common and destructive food spoilage fungi belong to the genera Aspergillus, Penicillium and Fusarium, although other genera are of significance in particular foods and feed (Refai and Hassan, 2013). Moreover, Candida albicans and other fungal infection are probably one of the most successful opportunistic pathogens in humans. Under conditions of a weakened immune system, colonizing $C$. albicans and mould can become pathogenic, causing recurrent mucosal infections and lifethreatening contagious infections with high mortality rates (Refai et al., 2014a). In addition, there are a number of fungal diseases which adversely affect the health of animal, as mastitis which is the major production-limiting disease causing staggering economic losses to the animal industry. The most important effects are related to economic losses due to decrease in milk yield (McDowell et al., 1995), Several studies recovered various fungal causes of these diseases in man and animals as $C$. albicans, Aspergillus sp. and Penicillium sp. which are the dominant microbial isolates in cases of mastitis (Yuan et al.,2012 and
Hassan et al., 2014 and 2015 a). Some mould as members of Aspergillus sp., Penicillium sp. and Fusarium sp. caused mycosis and mycotoxicosis in buffaloes (Hassan et al.,2008, 2010 and 2014), in poultry (Hassan et al., 2007) and in rabbits (Hassan et al., 2016).

Recently, a rapid increase in microbial infections that are resistant to conventional antibiotics has been observed, especially, the frequency of infections provoked by opportunistic fungal strains has increased dramatically (Goffeau, 2008; Nabawy et al., 2014 and Hassan et al., 2015a and 2016 ). Furthermore, the number of known multidrug resistant fungi is increasing rapidly. Thus, the development of more effective antifungal therapies is of great importance.

Because the factors that contribute to fungi proliferation include environmental and ecological conditions that often are beyond human control, world food contamination by fungi represents a significant problem (Hussein and Brasel, 2001 and Scussel, 2005). Therefore, numerous studies investigated the development of methods for fungide contamination as the use of modified atmospheres including carbon dioxide, nitrogen, oxygen and, more recently, ozone fumigation (Scussel et al.,2011a; Giordano et al., 2012 and Savi et al., 2014a\&b). One of the important applications of ozone in agricultureis the postharvest treatment of crops (Zorlugenic et al.2008) and reducing or eliminating undesirable mycoflora from grains and their by-products (Tiwari et al., 2010). Ozone acts through a progressive oxidation of vital cellular components on destroying microorganisms preventing the microbial growth, thus extending the shelf life of several foods(Guzel-Seydim et al., 2004 and Aguayo et al., 2006). These applications 
include the surface decontamination, food storage, and preservation, as well as packaging sterilization (Desvignes et al., 2008and Cárdenas et al., 2011).

Therefore, the present study was undertaken to investigate the fungal causes of mastitis in dairy buffaloes and the recovered fungi were subjected for ozone fumigation in comparison with some traditional chemical antifungal. In addition, the efficacy of ozone fumigation was evaluated by scanning electron microscope of the treated fungal spores and mycelia.

\section{Materials and Methods}

Samples: One hundred samples were collected from private farm of dairy buffaloes at Giza governorate suffering from repeated mastitis affection, 20 samples of each of (litters, swabs of workers hand and feeds) and 40 milk samples from diseased mastitis animals. The samples and swabs were aseptically transferred into sterile polyethylene bags, swabs or sterile container without delay and transported to the laboratory for further investigation.

Standards of antifungal agents: A known antifungals as ketoconazole and Fluconazole were used in comparison with ozone gas fumigation. It were manufactured and purchased from by sigma chemical company.

Ozone Gas Production: Ozone gas was produced from air using ozone generator Model OZO 6 VTTL (OZO MAX LTD, shefford, Quebec, Canda) from purified extra dry oxygen fed gas. The amount of output from ozone was controlled by a monitor-controller having a plug-in. sensor on a board which is changed for different ranges of ozone concentration and a belt pan in the monitor controller that allows controlling the concentration in a selected range.
Isolation and identification of fungi from samples collected from dairy buffaloes farm had cases of animal mastitis

One Ten grams of each sample or $1 \mathrm{ml}$ of immerse swab of workers hand or milk were transferred aseptically into sterile blender jar, to which $90 \mathrm{ml}$ of $1 \%$ peptone water were added and homogenized in a sterile warring blender for 2 minutes and tenfold serial dilutions of the homogenate were prepared (Refai, 1979). One milliliter quantities of the previously prepared serial dilutions were inoculated separately into Petri dish plates and mixed with Sabouraud dextrose agar medium. The plates were then left to solidify after mixing, and incubated at $25^{\circ} \mathrm{C}$ for $3-5$ days. The counts of mould and yeast colonies were recorded. Individual suspected colonies were selected depending upon their morphological characters. Stock culture were made from each isolate and monitored on Czapek- Dox, malt extract and potato dextrose (PDA) agar slopes for further identification. The identification of different species was carried out by observation of their macroscopic and microscopic characteristics of mould colonies according to, Pitt and Hocking (2009) and Refai and Hassan (2013).

Preparation of spore suspension of isolated mould and yeast isolated from dairy farm had mastitic animals (Gupta and Kohli, 2003)

At the end of incubation period (3-5 days), the mycelia spore mat was washed off with a $6 \mathrm{ml}$ of sterile distilled water and by sterile loop, the outer most layer of growth (spores) was scraped. The mycelia were removed by filtration through a $500 \mathrm{~mm}$ sieve. This spore suspension was counted in haemocytometer slide considering the dilution factor and the spores count was adjusted to the desired level. To each broth containing spore suspension a drop of tween 80 was added to keep the viability of the spore till used. 
Ozone treatment for controlling the fungal growth of isolates recovered from dairy buffaloes farm had mastitic animals (Ali, 2007)

Ozone was generated via a controlled flow of oxygen through a corona discharge in the ozone generator (OZO-2000). Ten $\mathrm{ml}$ of spore suspension of each of the most dominant fungal species recovered from dairy buffaloes farm had mastitic animals were held in ozone chamber and exposed at 20, 40 and $60 \mathrm{ppm}$ and the exposure times were for 0 (control), 5, 10, 15 and $20 \mathrm{~min}$. Linear growth $(\mathrm{cm})$ were measured after 7 days incubation at $28^{\circ} \mathrm{C}$. For each type of isolate a plates were used for each treatment as a control. One $\mathrm{ml}$ of each treatment was subjected to colony count as recommended by Refai and Hassan (2013) to report the effect of ozone treatment.

\section{Scanning electron microscope (SEM)} (Goldstein et al., 1992)

The samples of treated spores were coated by gold sputter coat (SPI Module) and examined by scanning SEM (JEOLJSM$5500 \mathrm{LV}$ ) by using high vacuum mode at the Regional Center of Mycology and Biotechnology, Cairo, Egypt to study the efficacy of treatment of fungi.

Determination the minimal inhibitory concentration (MIC) of some traditional antimycotic drugs (Gupta and Kohli, 2003)

One $\mathrm{ml}$ spore suspension from each tested isolate was poured in sterile Petri dishes and were over layered with Sabouraud's dextrose agar containing $1 \mathrm{ml}$ of different concentrations of the tested antimycotics (ketoconazole and Fluconazole) which are $(0.50,0.75,1.0,2.0,3.0$, and $4.0 \mu \mathrm{g} / \mathrm{ml}$ for ketoconazole and 5, 10, 15, $20 \mathrm{ug} / \mathrm{ml}$ for Fluconazole). The tested antifungals were prepared in 2 replicates. The plates were rotated to mix the content and allowed to solidify, at room temperature, then they were incubated at $25^{\circ} \mathrm{C}$ for $2-15$ days before reporting the MIC which was the concentration that prevented growth of fungus completely. All experiment were reported at least 3 times to obtain average data.

Evaluation the efficacy of ozone fumigation in control the fungal contamination in commercial animal feed (Ali, 2007 and Refai and Hassan, 2013)

Twenty of commercial animal feed that contaminated with fungi and related to the current mastitis cases of the present study were selected. Twenty five grams of each sample were exposed to ozone fumigation at 20, 40 and $60 \mathrm{ppm}$ and the exposure times were 0 (control), 5, 10, 15 and $20 \mathrm{~min}$. The total colony count of fungi was detected before and after treatment for evaluation the effective dose of ozone.

Statistical analysis (SPSS 14, 2006):The obtained data were computerized and analyzed for significance. Calculation of standard error and variance according to.

\section{Results and Discussion}

Buffaloes are an economically important source of milk and meat, there are about 3.98 million head in Egypt and several serious problem facing animals health including respiratory disorders, mastitis and diarrhea (Arab agriculture statistics year book (A.A.S., 2011). The mastitis is one of important infections of buffaloes is the mastitis which a frustrating, costly and extremely complex disease resulted in a marked reduction in the quality and quantity of milk (Akhtar et al., 2012). The pathogens that cause mastitis can be divided into different groups of organisms depending on 
the source of the organism involved; these include contagious and, environmental pathogens (Philpot and Nickerson, 1999). Moulds and yeasts are found on a wide variety of environmental factors such as feed, litters, air, soil, plants, water and animals discharges. The previous literatures recorded that the environmental pollution affect upon the growth rate and health of human being and animals and maycause several diseases as thrush, disseminated candidiasis, aspergillosis, dermatophytosis and mastitis, anemia, stunted growth, carcinogenic, tremor-genic, hemorrhagic, dermatitis, pulmonary edema, immunosuppressive and hormonal effects(Hassan, 2003 and Asfour et al., 2009; Hassan et al., 2009, 2014; 2015a and 2016and El-Hamaky et al., 2016). While, the mycotoxigenic fungi can induce both toxicological and immunologic effects in a variety of cell systems and animal species as cytotoxic effect to reticulocytes, fibroblasts and lymphocytes and the cellular toxicity appears to be mediated by the inhibition of protein synthesis as reported by (Mogeda et al., 2002; Hassan et al.,2015 b\&c and 2016). Whereas, other fungi as $C$. albicans is considered a commensal organism for humans and animals and when host defenses are compromised $C$. albicans can transform into a tissue invasive pathogen (Palmer, 2008)resulting in several affections of the oral cavity, gastrointestinal tract, animal abortion and skin diseases (Shawky et al.,2014; Hassan et al., 2015 and 2016). However, Candida sp. isrecognized as the fourth most common cause of blood stream infection, with a high attributable mortality rate, while, C.albicans remains the most common pathogen (Marr, 2004). The intestinal tract provides an important reservoir for many nosocomial pathogens, including Candida species and somebacterial species. Disruption of normal barriers, such as gastric acidity and endogenous microflora of the colon, facilitates the overgrowth of pathogens (Donskey, 2004). The reproductive tracts of different animals are the major reservoir of yeasts suchas $C$. albicans and C. neoformans (Radwan et al., 2008; Hassan et al., 2014 and Shawky et al., 2014).Several studies indicated that there was significant prevalence of fungal infection in cattle and buffaloes that infested with ticks. This may be due to the fact that toxins present in saliva of ticks result in immunosuppression of the animals. In cattle, it causes high economic losses as body weight loss, decreased meat and milk yield and the acceptance of live animals in the market would also be reduced (Hassan et al., $2015 \mathrm{a}$ and 2016).

In the present study, the current results in Table (1) illustrated thatthe most predominant members of Aspergillus species in samples of litters, feed, workers hand and mastitis milk that collected from mastitis buffaloes were belonging to A.flavus which recovered from $(90 \%, 60 \%, 40 \%, 25 \%)$, A.ochraceus from $(50 \%, 60 \%, 25 \%, 25 \%)$, A.niger from $(60 \%, 40 \%, 50 \%, 30 \%)$ and $A$. fumigates recovered from $(10 \%, 25 \%, 0 \%$, $40 \%$ ) of samples, respectively. While, Penicillium sp. and Fusarium sp. were recovered from $(20 \%$ and $25 \%)(25 \%$ and $15 \%)(0 \%$ and $0 \%)(25 \%$ and $0 \%)$ of litters, feed, workers hand and mastitis milk samples, respectively. On the other hand, C.albicans and Rhodotorula sp. were isolated at the rates of $(70 \%$ and $30 \%)(40$, $20 \%) \quad(50 \%, \quad 0 \%) \quad(37.5 \%, \quad 20 \%)$, respectively. Similar results were detected by Mosherf (2005), who reported that various Candida species particularly, $C$. albicans were the most common yeasts recovered from milk of clinically and subclinically mastitis milk. While, Hassan et al. (2012a) reported that yeast of $C$. albicans was recovered from $24 \%$ of mastitis cases. In other study, many mould isolates were 
recovered from mastitis milk of sheep and cattle (Hassan et al., 2010), who isolated Aspergillus flavus from animal feeds, mastitis milk and vaginal swabs at the rates of $(80 \%, 50 \%$ and $50 \%)$, respectively, while the rates of isolation for $A$. parasiticus were (35\%, 24\% and 10\%), respectively. However, Shawky et al.(2014) recovered $C$. albicans from cases of buffalo's abortion, where it was isolated from $20 \%$ of milk samples, $7.5 \%$ of placenta and $20 \%$ of fetal stomach contents, respectively.

Hence, up to date the active search for new pharmacologically active agents of natural sources was led to the discovery of many useful drugs which could play important role in treatment of many fungal and mycotoxin diseases with neither environmental pollution nor development of fungicide resistance pathogens.

In addition to, the continued evolution of drug resistance, which has already invalidated many routinely used antibiotics, has reached a fevered pitch and is a serious public health threat, with some even warning of the possibility of the 21 st century becoming the "post-antibiotic" era (Kåhrström et al., 2013).

Recently, various studies evaluated different methods in control the fungal growth as the use of ozone fumigation (Scussel et al., 2011a; Giordano et al., 2012 and Savi et al., $2014 \mathrm{a} \& \mathrm{~b})$. One of the important applications of ozone in agriculture is the postharvest treatment of crops (Zorlugenic et al., 2008), reducing or eliminating undesirable mycoflora from grains and their by-products (Tiwari et al., 2010). Although commercial ozone application for grain management is not well documented, there are numerous studies that describe the potential benefits of that technology (McDonough et al., 2011).Ozone efficacy depends on several factors that include its concentration applied, the characteristics of each food, and environmental factors such as temperature and humidity.

Currently, the predominant isolates that recovered from samples related to mastitis were subjected for ozone fumigation in parallel with traditional chemical antifungals. The effectiveness of ozone treatments on spore germination was a function of ozone concentration and treatment duration. The gradual increase in ozone concentration induced progressive retardation of the spore viability and the required time for exposure was decreased. Where, the growth inhibition of mould as A.flavus that recovered from cases of mastitis required exposure to $20 \mathrm{ppm}$ for 20 minutes ; to $40 \mathrm{ppm}$ for 15 minutes and exposure to $60 \mathrm{ppm}$ for 10 minutes to be completely inhibited their growth and no mycelial growth was observed (Tables, $2,3,4 \& 5)$. The ozone exposure of mould for time under 10 minutes not able to inhibit completely their growth and the inhibition was more pronounced with the extension of exposure time. Whereas, any increase in the exposure time at any concentration of gaseous ozone resulted in a significant gradual retardation in growth of mould and accordingly the inhibition efficiency increased with the increase in ozone concentration.

On the other hand, the growth inhibition of yeast was more sensitive for ozone fumigation which required fewer time of exposure (5-10 $\mathrm{min})$. This is related the differences in structures and the presence of profuse mycelial mass in case of mould which require elongated time of exposure than the cellular structure of yeast (GuzelSeydim et al., (2004). In addition, during food storage, spores are the major source of inoculums. Hence reduction or inhibition of 
spore production is very advantageous in food storage facilities. Such inhibition/reduction of spore production has been previously observed in fungi cultured under ozone rich environment (AntonyBabu and Singleton, 2009). Similarly, the ozone gas is known to possess antimicrobial activity and thereby at higher concentrations could be used to reduce the initial load of contaminants on feed and food and to disinfect storage and processing areas (Najafi and Khodaparast, 2009 and Korzun et al., 2008).

Regarding the use of traditional antifungal agents, it has been reported that the potency ketoconazole and fluconazole against fungi isolated from cases of buffaloes mastitis showed that the effective inhibitory concentrations that inhibited all fungi by ketoconazole was $4 \mathrm{ug} / \mathrm{ml}$ and fluconazole was $20 \mathrm{ug} /$ $\mathrm{ml}$. The obtained data confirm data reported by Hassan (1994); Hassan and El Sharnou by (1997); Neil et al. (1998); Okeke et al. (2000) and Nakashima et al. (2002).Whereas, Various studies in different laboratories showed that antifungals as Azolesinhibit sterol formation and polyenes that bind to mature membrane sterols have been regarded antifungal therapy for several decades (Kullberg and Pauw, 1999; and Sheehan et al., 1999). On the other hand, Amphotericin B and fluconazole were used as a positive control toward fungi; amphotericin B is a fungicidal agent widely used in treating serious systemic infections (Hartsel and Bolard. 1996) and fluconazole is used in the treatment of superficial skin infections caused by dermatophytes and Candida species (Boazand Marcelo, 1998).

In the present study, the treated fungi with ozone fumigation were subjected to scanning by electron microscopy (SEM) to detect the changes in the morphological structures of fungal elements which resulted from treatment. The results revealed that all treated fungi showed many destructive changes in morphology and loss of cell integrity and hence its viability and function inhibited. When ozone concentrations and time of exposure increased, a serious and destructive changes to fungal structure would occur(Photo 1-4).

Similar findings to our results were detected by several studies as that illustrated by Guzel-Seydim et al. (2004) and Ali (2006), who stated that there are two major mechanisms identified in ozone destruction of the target organisms ; the first mechanism is that ozone oxidize sulfhydryl groups and amino acids of enzymes, peptides and proteins to shorter peptides. While, the second mechanism is that ozone oxidizes polyunsaturated fattyacids to acid peroxides. The differential activity of ozone against the test fungi might be due to the variation in their organic matter content which may accelerate orreduce the toxicity of ozone. Similarly, Ali (2006),found that the specific interaction of sucrose or polysaccharides with ozone affects the ozone activity. Other study suggested that the photolysis of ozone to oxygen atoms could lead to the generation of the hydroxyl radical $(\mathrm{OH})$, a key reactive species during the decomposition process (Jans and Hiogne, 1998) and the inhibition of mycelialgrowth and sporulation of fungal cell due to oxidizingaction of ozone as de4tected by Liew and Prange (1994).

Recently, it is suggested that ozone penetrates cellmembrane and reacts with cytoplasmic substances and chromosomal DNA which affected by ozone degradation and its damage occur which may be one of the factors responsible for the cell killing (Todar, 2009 and El-Desouky et al., 2012). 
Also, ozone concentrations at ground levels modulate oxidative DNA damage (Palli et al., 2009).

Currently, as the animal feeds are the main sources of infections in animal diseases, the field application of the present results on selected highly contaminated commercial animal feed with different moulds, evidenced also higher potential antifungal effects of the ozone fumigation. Where, all used concentrations of ozone $(20,40 \& 60$ ppm) were effective in decontamination when contaminated feed exposed for 20 minutes and more (Table, 6). These results were in agreement with other studies in this respect (Antony-Babu and Singleton (2009); Gabler et al., 2010 and Alencar et al., 2012).

Table.1 Prevalence of fungi in samples collected from dairy buffaloes farm had cases of recurrent mastitis in buffaloes

\begin{tabular}{|l|l|l|l|l|l|l|l|l|}
\hline \multirow{2}{*}{$\begin{array}{l}\text { Genera of } \\
\text { isolated fungi }\end{array}$} & \multicolumn{6}{|c|}{ Samples collected from cases of mastitis } \\
\cline { 2 - 11 } & $\begin{array}{l}\text { litters } \\
(20)\end{array}$ & \multicolumn{2}{l}{$\begin{array}{l}\text { Ration } \\
(20)\end{array}$} & \multicolumn{2}{l|}{$\begin{array}{l}\text { Workers } \\
\text { Hand (20) }\end{array}$} & \multicolumn{2}{l|}{$\begin{array}{l}\text { Mastitis Milk } \\
(40)\end{array}$} \\
\hline & No. & $\%$ & No. & $\%$ & No. & $\%$ & No. & $\%$ \\
\hline Aspergillus fluves & $\mathbf{1 6}$ & $\mathbf{9 0}$ & $\mathbf{1 2}$ & $\mathbf{6 0}$ & $\mathbf{8}$ & $\mathbf{4 0}$ & $\mathbf{1 0}$ & $\mathbf{2 5}$ \\
\hline Aspergillus ochraceus & $\mathbf{1 0}$ & $\mathbf{5 0}$ & $\mathbf{1 2}$ & $\mathbf{6 0}$ & $\mathbf{5}$ & $\mathbf{2 5}$ & $\mathbf{1 0}$ & $\mathbf{2 5}$ \\
\hline A.fumigatus & $\mathbf{2}$ & $\mathbf{1 0}$ & $\mathbf{5}$ & $\mathbf{2 5}$ & - & -- & $\mathbf{1 6}$ & $\mathbf{4 0}$ \\
\hline Aspergillus niger & $\mathbf{1 2}$ & $\mathbf{6 0}$ & $\mathbf{8}$ & $\mathbf{4 0}$ & $\mathbf{1 0}$ & $\mathbf{5 0}$ & $\mathbf{1 2}$ & $\mathbf{3 0}$ \\
\hline Penicillum species & $\mathbf{4}$ & $\mathbf{2 0}$ & $\mathbf{5}$ & $\mathbf{2 5}$ & - & - & $\mathbf{1 0}$ & $\mathbf{2 5}$ \\
\hline Fusarium species & $\mathbf{5}$ & $\mathbf{2 5}$ & $\mathbf{3}$ & $\mathbf{1 5}$ & - & - & - & - \\
\hline Cladosporium species & $\mathbf{4}$ & $\mathbf{2 0}$ & $\mathbf{6}$ & $\mathbf{3 0}$ & $\mathbf{1 0}$ & $\mathbf{5 0}$ & - & - \\
\hline Scopulariopsis species & $\mathbf{2}$ & $\mathbf{1 0}$ & - & - & - & - & $\mathbf{4}$ & $\mathbf{1 0}$ \\
\hline Mucor species & - & - & - & - & $\mathbf{8}$ & $\mathbf{4 0}$ & $\mathbf{6}$ & $\mathbf{1 5}$ \\
\hline Candida species & $\mathbf{1 4}$ & $\mathbf{7 0}$ & $\mathbf{8}$ & $\mathbf{4 0}$ & $\mathbf{1 0}$ & $\mathbf{5 0}$ & $\mathbf{1 5}$ & $\mathbf{3 7 . 5}$ \\
\hline Rhodotorula species & $\mathbf{6}$ & $\mathbf{3 0}$ & $\mathbf{4}$ & $\mathbf{2 0}$ & - & - & $\mathbf{8}$ & $\mathbf{2 0}$ \\
\hline
\end{tabular}

Table.2 Influence of Ozone fumigation (20 PPM)and time of exposure on the growth fungal isolates that recovered from cases of mastitis in buffaloes

\begin{tabular}{|c|c|c|c|c|c|c|}
\hline \multirow[t]{2}{*}{ Fungal isolates } & \multirow{2}{*}{$\begin{array}{l}\text { Dose of } \\
\text { ozone } \\
\text { exposure }\end{array}$} & \multirow{2}{*}{$\begin{array}{l}\text { C.C. Before } \\
\text { Ozone } \\
\text { treatment }\end{array}$} & \multicolumn{4}{|c|}{$\begin{array}{l}\text { C.C. of fungi at different exposure times of } \\
\text { ozone fumigation }\end{array}$} \\
\hline & & & 5 min. & $10 \mathrm{~min}$. & $15 \mathrm{~min}$. & 20 min. \\
\hline Aspergillus flavus & 20 ppm & $1 \times 10^{7}$ & $10^{5}$ & $10^{3}$ & $10^{1}$ & $\mathbf{0}$ \\
\hline A. ochraceus & $20 \mathrm{ppm}$ & $3 \times 10^{6}$ & $10^{4}$ & $10^{3}$ & $10^{1}$ & $\mathbf{0}$ \\
\hline A.niger & 20ppm & & $10^{3}$ & $\mathbf{0}$ & $\mathbf{0}$ & $\mathbf{0}$ \\
\hline A.fumigatus & 20ppm & $2 \times 10^{5}$ & $10^{3}$ & $10^{2}$ & $\mathbf{0}$ & $\mathbf{0}$ \\
\hline Penicillium sp. & 20ppm & $1 \times 10^{6}$ & $10^{3}$ & $10^{2}$ & 10 & $\mathbf{0}$ \\
\hline Fusarium sp. & 20ppm & $4 \times 10^{4}$ & $10^{3}$ & $10^{2}$ & 10 & $\mathbf{0}$ \\
\hline Mucor sp. & 20ppm & $2 \times 10^{6}$ & $10^{2}$ & 10 & $\mathbf{0}$ & $\mathbf{0}$ \\
\hline Rhizopus sp. & 20ppm & $3 \times 10^{5}$ & $10^{2}$ & 10 & $\mathbf{0}$ & $\mathbf{0}$ \\
\hline Candida sp. & 20ppm & $2 \times 10^{5}$ & 10 & $\mathbf{0}$ & $\mathbf{0}$ & $\mathbf{0}$ \\
\hline Rhodotorula $s p$ & 20ppm & $1 \times 10^{5}$ & 10 & $\mathbf{0}$ & $\mathbf{0}$ & $\mathbf{0}$ \\
\hline
\end{tabular}

The inhibitory Concentration for all fungi for ketoconazole was $4 \mathrm{ug} / \mathrm{ml}$ and fluconazole was $20 \mathrm{ug} / \mathrm{ml}$. 
Table.3 Influence of Ozone fumigation (40 PPM) and time of exposure on the growth fungal isolates that recovered from cases of mastitis in buffaloes

\begin{tabular}{|c|c|c|c|c|c|c|}
\hline \multirow[t]{2}{*}{ Fungal isolates } & \multirow{2}{*}{$\begin{array}{l}\text { Dose of } \\
\text { ozone } \\
\text { exposure }\end{array}$} & \multirow{2}{*}{$\begin{array}{l}\text { C.C. Before } \\
\text { Ozone } \\
\text { treatment }\end{array}$} & \multicolumn{4}{|c|}{$\begin{array}{l}\text { C.C. of fungi at different exposure times of } \\
\text { ozone fumigation }\end{array}$} \\
\hline & & & 5 min. & 10 min. & 15 min. & 20 min. \\
\hline Aspergillus flavus & 40 ppm & $1 \times 10^{7}$ & $10^{3}$ & 10 & 0 & 0 \\
\hline A. ochraceus & $40 \mathrm{ppm}$ & $3 \times 10^{6}$ & $10^{3}$ & $10^{2}$ & $\mathbf{0}$ & 0 \\
\hline A.niger & $40 \mathrm{ppm}$ & & 10 & 0 & $\mathbf{0}$ & $\mathbf{0}$ \\
\hline A.fumigatus & $40 \mathrm{ppm}$ & $2 \times 10^{5}$ & $10^{2}$ & 10 & $\mathbf{0}$ & $\mathbf{0}$ \\
\hline Penicillium sp. & $40 \mathrm{ppm}$ & $1 \times 10^{6}$ & $10^{3}$ & $10^{2}$ & $\mathbf{0}$ & $\mathbf{0}$ \\
\hline Fusarium sp. & $40 \mathrm{ppm}$ & $4 \times 10^{4}$ & $10^{3}$ & $10^{2}$ & $\mathbf{0}$ & $\mathbf{0}$ \\
\hline Mucor sp. & $40 \mathrm{ppm}$ & $2 \times 10^{6}$ & $10^{2}$ & 10 & $\mathbf{0}$ & $\mathbf{0}$ \\
\hline Rhizopus sp. & $40 \mathrm{ppm}$ & $3 \times 10^{5}$ & $10^{2}$ & 10 & $\mathbf{0}$ & $\mathbf{0}$ \\
\hline Candida sp. & $40 \mathrm{ppm}$ & $2 \times 10^{5}$ & 10 & $\mathbf{0}$ & $\mathbf{0}$ & $\mathbf{0}$ \\
\hline Rhodotorula sp & $40 \mathrm{ppm}$ & $1 \times 10^{5}$ & 10 & $\mathbf{0}$ & $\mathbf{0}$ & $\mathbf{0}$ \\
\hline
\end{tabular}

The inhibitory Concentration for all fungi by ketoconazole was $4 \mathrm{ug} / \mathrm{ml}$ and fluconazole was $20 \mathrm{ug} / \mathrm{ml}$.

Table.4 Influence of Ozone fumigation $(60 \mathrm{ppm})$ and time of exposure on the growth fungal isolates that recovered from cases of mastitis in buffaloes

\begin{tabular}{|c|c|c|c|c|c|c|}
\hline \multirow[t]{2}{*}{ Fungal isolates } & \multirow{2}{*}{$\begin{array}{l}\text { Dose of } \\
\text { ozone } \\
\text { exposure }\end{array}$} & \multirow{2}{*}{$\begin{array}{l}\text { C.C. Before } \\
\text { Ozone } \\
\text { treatment }\end{array}$} & \multicolumn{4}{|c|}{$\begin{array}{l}\text { C.C. of fungi at different exposure times of } \\
\text { ozone fumigation }\end{array}$} \\
\hline & & & 5 min. & $10 \mathrm{~min}$. & 15 min. & 20 min. \\
\hline Aspergillus flavus & 60 ppm & $1 \times 10^{7}$ & $10^{2}$ & 0 & 0 & 0 \\
\hline A. ochraceus & $60 \mathrm{ppm}$ & $3 \times 10^{6}$ & $10^{2}$ & $\mathbf{0}$ & $\mathbf{0}$ & $\mathbf{0}$ \\
\hline A.niger & $60 \mathrm{ppm}$ & & 10 & $\mathbf{0}$ & $\mathbf{0}$ & $\mathbf{0}$ \\
\hline A.fumigatus & $60 \mathrm{ppm}$ & $2 \times 10^{5}$ & $10^{T}$ & $\mathbf{0}$ & $\mathbf{0}$ & $\mathbf{0}$ \\
\hline Penicillium $s p$. & $60 \mathrm{ppm}$ & $1 \times 10^{6}$ & $10^{2}$ & $\mathbf{0}$ & $\mathbf{0}$ & $\mathbf{0}$ \\
\hline Fusarium sp. & $60 \mathrm{ppm}$ & $4 \times 10^{4}$ & $10^{2}$ & $\mathbf{0}$ & $\mathbf{0}$ & $\mathbf{0}$ \\
\hline Mucor sp. & $60 \mathrm{ppm}$ & $2 \times 10^{6}$ & $10^{1}$ & $\mathbf{0}$ & $\mathbf{0}$ & $\mathbf{0}$ \\
\hline Rhizopus sp. & $60 \mathrm{ppm}$ & $3 \times 10^{5}$ & $10^{1}$ & $\mathbf{0}$ & $\mathbf{0}$ & $\mathbf{0}$ \\
\hline Candida sp. & $60 \mathrm{ppm}$ & $2 \times 10^{5}$ & $\mathbf{0}$ & $\mathbf{0}$ & $\mathbf{0}$ & $\mathbf{0}$ \\
\hline Rhodotorula sp & $60 \mathrm{ppm}$ & $1 \times 10^{5}$ & $\mathbf{0}$ & $\mathbf{0}$ & $\mathbf{0}$ & $\mathbf{0}$ \\
\hline
\end{tabular}

The inhibitory Concentration for all fungi by ketoconazole was $4 \mathrm{ug} / \mathrm{ml}$ and fluconazole was $20 \mathrm{ug} / \mathrm{ml}$. 
Table.5 Comparison between effective inhibitory times of different doses of ozone fumigation on the growth fungal isolates that recovered from cases of mastitis in buffaloes

\begin{tabular}{|l|l|l|l|}
\hline Fungal isolates & $\begin{array}{l}\text { Maximum effective } \\
\text { exposure time of } \\
\text { ozone fumigation at } \\
20 \text { ppm (minutes) }\end{array}$ & $\begin{array}{l}\text { Maximum } \\
\text { effective exposure } \\
\text { times of ozone } \\
\text { fumigation at 40 } \\
\text { ppm(minutes) }\end{array}$ & $\begin{array}{l}\text { Maximum } \\
\text { effective exposure } \\
\text { time of ozone } \\
\text { fumigation at 60 } \\
\text { ppm (minutes) }\end{array}$ \\
\hline Aspergillus flavus & $\mathbf{2 0}$ & $\mathbf{1 5}$ & $\mathbf{1 0}$ \\
\hline A. ochraceus & $\mathbf{2 0}$ & $\mathbf{1 5}$ & $\mathbf{1 0}$ \\
\hline A.niger & $\mathbf{1 5}$ & $\mathbf{1 0}$ & $\mathbf{1 0}$ \\
\hline A. fumigatus & $\mathbf{1 5}$ & $\mathbf{1 5}$ & $\mathbf{1 0}$ \\
\hline Penicillium $s p$. & $\mathbf{2 0}$ & $\mathbf{1 5}$ & $\mathbf{1 0}$ \\
\hline Fusarium $s p$. & $\mathbf{2 0}$ & $\mathbf{1 5}$ & $\mathbf{1 0}$ \\
\hline Mucor $s p$. & $\mathbf{1 5}$ & $\mathbf{1 5}$ & $\mathbf{1 0}$ \\
\hline Rhizopus $s p$. & $\mathbf{1 5}$ & $\mathbf{1 5}$ & $\mathbf{1 0}$ \\
\hline Candida $\mathrm{sp}$. & $\mathbf{1 0}$ & $\mathbf{1 0}$ & $\mathbf{5}$ \\
\hline Rhodotorula $s p$ & $\mathbf{1 0}$ & $\mathbf{1 0}$ & $\mathbf{5}$ \\
\hline
\end{tabular}

Table.6 Total colony count of commercial feed (20 samples) after treatment with ozone fumigation

\begin{tabular}{|c|c|c|c|c|}
\hline \multirow{2}{*}{$\begin{array}{l}\text { Doses of } \\
\text { ozone }\end{array}$} & \multicolumn{4}{|c|}{ C.C. at different times of exposure for ozone } \\
\hline & $5 \mathrm{~min}$. & $10 \mathrm{~min}$. & $15 \mathrm{~min}$ & 20 min. \\
\hline 0 ppm & $1 \times 10^{7}$ & $1 \times 10^{7}$ & $1 \times 10^{7}$ & $1 \times 10^{7}$ \\
\hline 20 ppm & $1 \times 10^{6}$ & $1 \times 10^{5}$ & $1 \times 10^{2}$ & $\mathbf{0}$ \\
\hline $40 \mathrm{ppm}$ & $1 \times 10^{5}$ & $1 \times 10^{4}$ & $1 \times 10^{1}$ & $\mathbf{0}$ \\
\hline 60 ppm & $1 \times 10^{4}$ & $1 \times 10^{1}$ & 0 & $\mathbf{0}$ \\
\hline
\end{tabular}
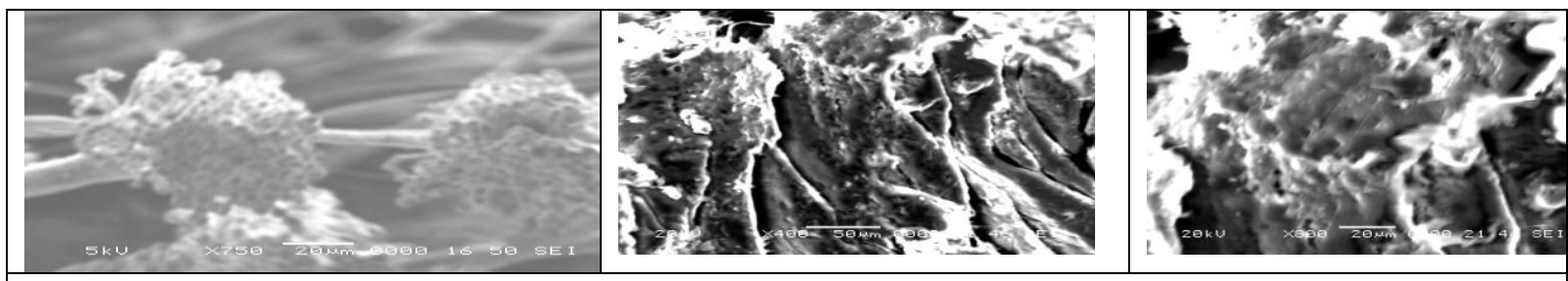

Photo (1) A.flavus : (A) Scanning electron micrographs of before exposure to ozone. Showed intact conidial head and conidiophore of fungus (B) After exposure to lower concentration of ozone therapy for 10 min- clumps of conidia. (C) after exposure to ozone for 20 minutes - loss of cell integrity and viability 

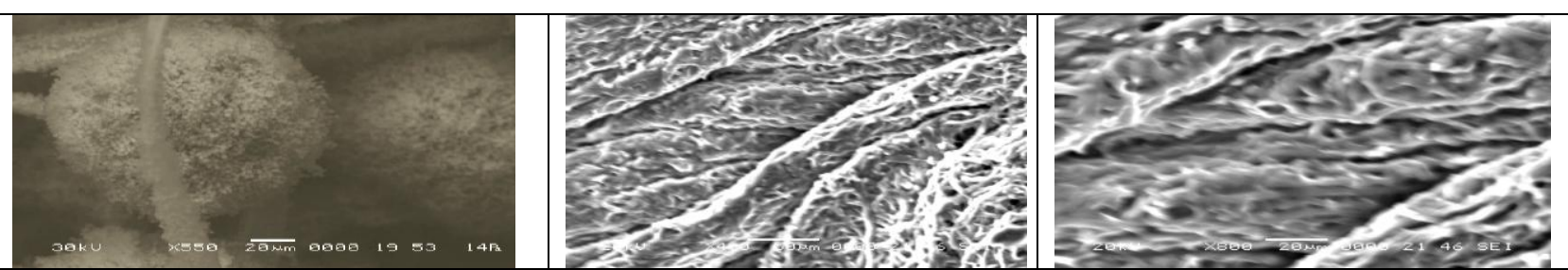

Photo (2) A.niger : (A) Scanning electron micrographs of before exposure to ozone. Showed intact conidial head and conidiophore of fungus (B) After exposure to lower concentration of ozone therapy for $10 \mathrm{~min}$ - clumps of conidia. (C) after exposure to ozone for 20 minutes- loss of cell integrity and viability
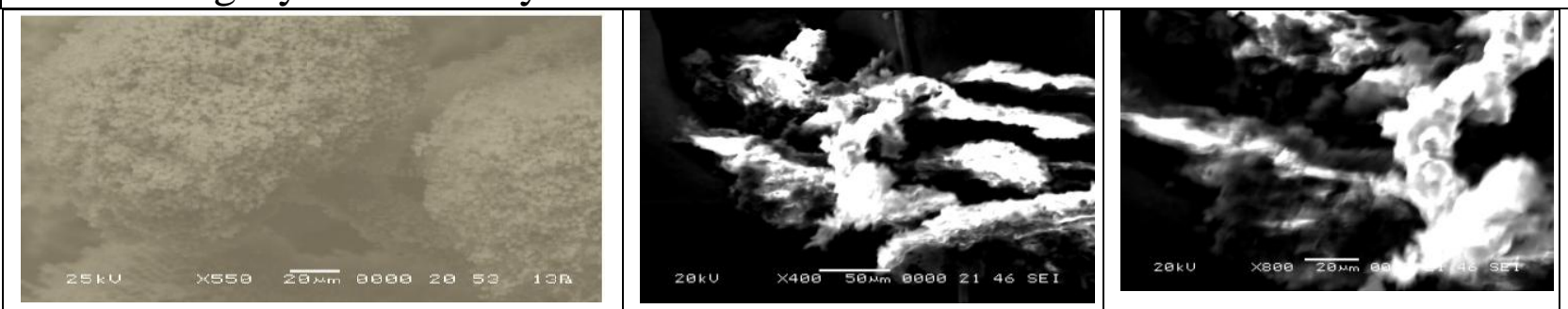

Photo (3) A.ochraceus : (A) Scanning electron micrographs of before exposure to ozone. Showed intact conidial head and conidiophore of fungus (B) After exposure to lower concentration of ozone therapy for 10 min- clumps of conidia. (C) after exposure to ozone for 20 minutes- loss of cell structural integrity and viability

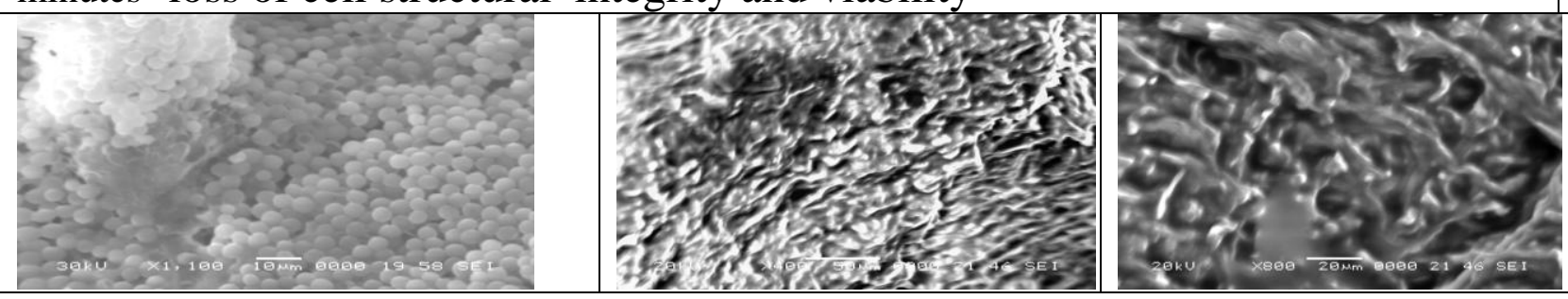

Photo (4) C.albicans: (A) Scanning electron micrographs of before exposure to ozone. Showed large clusters of yeast cells (B) After exposure to lower concentration of ozone therapy for 10 min- small clumps of cells. (C) after exposure to ozone for 20 minutes- loss of cell integrity and viability

Furthermore, this approach using ozone gas could be put into practice, where higher concentrations can impart surface sanitation of storage facilities and food handling equipment and storage and preservation (ElDesouky et al., 2012).

Therefore, fumigation with ozone gas can be a good method for achieving sanitation and decreasing initial microbial load in feed facilities and spoilage on a long term. Otherwise, the animal diseases could be prevented when healthy feed, disinfect storage, processing areas and other utensils which significantly reflected in improving animal health.

In conclusion, several fungal isolates that recovered from recurrent mastitis in buffalo were reported as potential pathogens and can cause other diseases conditions, particularly after prolonged exposure to adverse environmental conditions. The dangers of fungi besides caused animal diseases, they may produce fungal mycotoxins which are carcinogenic for animal and human. 
Therefore, the essential significance of this study is the indication that ozone fumigation can be used as inhibitor for the growth of fungi and could be used in the field of veterinary medicine as a fungicide in successful treatment of fungal diseases. The antifungal potential of ozone is due to the damage of the fungal cell wall of the microbial cells leading to leakage of the cell contents and finally cell death. In addition to the treatment of the serious fungal diseases as mycotic mastitis by traditional Chemical and mechanical sterilization methods adversely affect public health as well as the environment. Ozone fumigation can be successfully used for reducing the microbial loads. Hence, for this reason ozone may replace chemical antifungal agent.

\section{References}

A.A.S. (Arab Agriculture Statistics yearbook), 2011: Arabagriculture statistics yearbook. Khartoum, Sudan, ArabOrganization for Agriculture Development, League of ArabStates, p. 212. (No.19)

Aguayo, E., Escalona, V.H. and Artes, F. 2006. Effect of cyclic exposure to ozone gas on physicochemical, sensorial and microbial quality of whole and sliced tomatoes.

Aguilar, B., Amorena, B. and Iturralde, M. 2001. Effect of slime on adherence of Staphylococcus aureus isolated from bovine and ovine mastitis. Vet. Microbiol., 78: 183-191.

Akhtar, M.H., Ray, G.P., Singn, A.P., Sinna, B.R., Kumar, A. and Kumar, R. 2012. Efficacy of enrofloxacin Madison, WI, pp: 151-188.treatment for clinical mastitis in crosses bred cows. In: Compendium of Round Table Conference on Mastitis, pp: 178-184.

Alencar, E.R., Faroni, L. R., Soares, N. F., Silva, W.A. and Carvalho, M.C. 2012. Efficacy of ozone as a fungicidal and detoxifying agent of aflatoxins in peanuts, J. Sci. Food Agric., 92(4), 899-905.

Ali, E.M. 2006. Evaluation of ozone as inhibitory agent for microbial growth on contaminated dry herb and spices. MSc, Thesis, Faculty of Science, Biology Department, Cairo University.

Ali, E.M. 2007. Evaluation of ozone as a microbial disinfecting agent for dried herbs and spices. MS Thesis, Faculty of Science, Biology Department, Cairo University, 2007.

Antony-Babu, S. and Singleton, I. 2009. Effect of ozone on spore germination, spore production and biomass production in two Aspergillus species. Antonie van Leeuwenhoek, Int. J. General and Mol. Microbiol., 96(4), 413-422.

Asfour H.A.E., El-Metwally A.E. and Kotb M.H. 2009. Yeast as a cause of bovine mastitis and their histopathological effect on the mammary gland tissues. J. Egypt. Vet. Med. Assoc., 69(4. 41-72.

Boaz, A. and H.G. Marcelo. 1998. Adverse drug reactions ofthe new oral antifungal agents - terbinafine, fluconazole, and itraconazole. Int. J. Dermatol., 37: 410415

Cardenas, F.C., Andres, S., Giannuzzi, L. and Zaritzky, N. 2011. Antimicrobial action and effects on beef quality attributes of a gaseous ozone treatment at refrigeration temperatures. Food Control, 22: 14421447.

Desvignes, C., Chauranda, M., Dubois, M., Sadoudi, A., Abecassis, J. and LullienPellerin, V. 2008. Changes in common wheat grain milling behavior and tissue mechanical properties following ozone treatment. J. Cereal Sci., 47, 245-251.

Donskey C.J. 2004. The role of the intestinal tract as a reservoir and source for transmission of nosocomial pathogens. Clin. Infect. Dis., 39(2): 219-226.

El-Hamaky, A.M., Atef, A. Hassan, Heidy Abo El Yazeed and M.K. Refai. 2016. Prevalence and Detection of Toxigenic $A$. flavus, A.niger and A. ochraceus by traditional and molecular biology methods in feeds. Int. J. Curr. Res., Vol. 8, Issue, $1, \mathrm{pp}$.

El-Desouky, T. A., Sharoba, A. M. A., A. I. ElDesouky, El-Mansy, H. A, KhayriaNaguib. 2012. Evaluation of ozone gas as an anti-aflatoxin B1 in wheat 
grains during storage. Journal of Agroalimentary Processes and Technologies, 18 (1), 13-19.

Gabler, F. M., Smilanick, J. L., Mansour, M. F. and Karaca, H. 2010. Influence of fumigation with high concentrations of ozone gas on postharvest gray mould and fungicide residues on table grapes., Postharvest Biol., Technol., 55:85-90.

Giordano, B.N.E., Nones, J. and Scussel, V.M. 2012. Susceptibility of the in-shell Brazil Nutmycoflora and aflatoxin contamination to ozone gas treatment during storage. J. Agr. Sci. 4, 1-10.

Goffeau, A. 2008. Drug resistance: the fight against fungi. Nature, Vol. 452, No. 7187, (April) 541-542, ISSN 0028-0836.

Goldstein JI, Newbury DE, Echlin PE, Joy DC, Romig AD, Lyman CE, Fiori C, Lifshin E (1992. Scanning electron microscopy and X-ray microanalysis. Plenum, New York.

Gupta, A.k. and Kohli, Y. 2003.In-vitro susceptibility testing of ciclopirox, terbinafine, Ketoconazole and Itraconazole against dermatophytes and non-dermatophytes, and in vitro evaluation of combination antifungal activity. Br. J. Dermatol., 149 : 296-306.

Guzel-Seydim Z, Greene A, Seydim A (2004) Use of ozone in the food industry LebensonWissTechnol 37:453-460.

Hartsel, S. and J. Bolard. 1996. Amphotericin B: New life for an old drug. Trends Pharmacol. Sci., 17: 445-449.

Hassan, A.A. 1994. Detection and Control of Ochratoxin in food and feedstuffs. Ph.D. Thesis, Microbiology Dept. Fac. Vet. Med. Cairo University.

Hassan, A.A. and El-Shornouby, R. 1997. Antimicrobial effect of some chemicals and plant extracts on Egyptian food. J. Egypt. Vet. Med. Assoc., 57 (4. 13311349.

Hassan, A. A., Mogda, K. M,, Ibrahim, E.M., Naglaa M. A., Flourage, A.M. A., Rady, M. and Darwish A.S. 2016. Aflatoxicosis in Rabbits With Particular Reference to Their Control by N. Acetyl Cysteine and Probiotic. InternationalJournal of Current Research, Vol. 8, Issue, 1, pp.

Hassan, A. A.,Manal, A. Hassan,Rasha, M.H.
Sayed El Ahl and Darwish, A.S. 2012a. Prevalence of yeast infections in small ruminants with particular references to their treatment by some natural herbal extracts. Bull. Environ. Pharmacol. Life Sci., Volume 1, Issue 3, February 2012: 12-22.

Hassan, A.A., Howayda, M. El Shafei, Noha, H. Oraby, Rasha, M.H. Sayed El Ahl and Mogeda, K. Mansour.2012b.Studies on mycosis and mycotoxicosis in cattle. 1st Conf. of An. Health Res. Inst. Assoc., December 2012. pp. 216-227.

Hassan, A. A., Noha H. Oraby, El-Dahshan, E.M. E. and Ali, M.A. 2015 a. Antimicrobial Potential of Iron Oxide Nanoparticles in Control of Some Causes of Microbial Skin Affection in Cattle. European J. Academic Essays, 2(6. 2031.

Hassan, A.A., Rashid, M.A.,Minshawy M.M. and Noha, H. Oraby.2015b.Efficacy of chitinolyic enzyme produced by some soil fungi (Candida albicans and Aspergillusfumigatus) in biological control of cattle ticks. Int. J. Res. Studies in Biosci., (IJRSB), Vol. 3, Issue 2, ISSN 2349-0365 (Online) under Academicians' Research Center (ARC).

Hassan, A. A., Hanan K. Mahmoud, Taha H., Rasha M.H. Sayed El-Ahl and Mahmoud, H. H.2015 c. Herbal biosynthesis of zinc Nanoparticles and evaluation of their antifungal and antibacterial effect for buffaloes skin affections. Int. J. Curr. Res., Vol. 7, Issue, 12, pp. 24338-24349.

Hassan, A. A., Hammad, A.M. and Manal, A. Hassan, 2008. Prevalence of some dermatophytes and yeasts infections in cattle and their sensitivity to some antimycotics. The 5 th Scientific Congress, Minufiya Vet. J. Vol.5 (1. 2739.

Hassan, A. A., Ramadan M. Khoudair; and EL Sayed E. Younis. 2009. The Effect of Some Mycotoxins on Immunity of Cattle Vaccinated against Brucellosis and Guinea Pigs Experimentally Vaccinated With S19 Vaccine. Egypt. J. Appl. Sci., Vol. 24 No. 2 A) 2009 (1-13).

Hassan, A., A., Mogda, K. Mansour; Samira, 
A.M. Snousi; and Randa, A. Hassan. 2010. Mycological, biochemical and histopathological studies on acute fusariotoxicosis in sheep. Life Science J., Vol 7, No 3, 49-57.

Hassan, A.A. 2003. Detection of some mycotoxins and mycotoxins producing fungi in both macro- and microenvironment of diseased animals. 7th Sci. Cong. Egyptian Society for Cattle Diseases, pp. 112 - 119, 7-9 Dec., 2003, Assiut, Egypt.

Hassan, A.A., Noha, H. Oraby, Aliaa.A. E. Mohamed and Mahmoud H.H.2014.The possibility of using Zinc Oxide nanoparticles in controlling some fungal and bacterial strains isolated from buffaloes. Egypt. J. of Appl. Sci., 29 (3), 58-83.

Hassan, A.A., El-Barawy, A.M. and El-Mokhtar, Nahed,M. 2011.Evaluation of biological compound of Streptomyces species for control of some fungal diseases. $J$. of American Sci., 7 (4), 752-760.

Hassan, A.A; El Barawy, A.M and Manal, Hassan, 2007.Screening of meat and dairy byproducts for Candida albicance and effect of some antifungal on growth and germ tube formation of its isolates in Giza Governorate. Egypt. J. Comp. Path. \& Clinic. Path., 20 (1. 333-342.

Hussein, S. and Brasel, J.M. 2001. Toxicity, metabolism, and impact of mycotoxins on humans and animals. Toxicol., 167, 101134.

Jans, U. and Hiogne, J. 1998. Activated carbon and carbon black catalyzed transformation of aqueous ozone into OH-radicals. Ozone Sci. Eng., 20: 67-90.

Kåhrström, C.T. 2013. Entering a postantibiotic era? Nat. Rev. Microbiol., 2013;11: 146.

Khan, M.Z. and Khan, A., 2006. Basic facts of mastitis in dairy animals: a review. Pakistan Vet. J., 26(4): 204-208.

Korzun, W., Hall, J. and Sauer, R. 2008. The effect of ozone on common environmental fungi. Clin. Lab. Sci., 21:107-111.

Kullberg, B.J. and de, Pauw, B.E. 1999.Therapy of invasivefungal infections. Netherlands J. Medicine, Vol.55, No. 3, (September)
118-127, ISSN 0300-2977.

Liew, C.L. and Prange, R.K. 1994. Effect of ozone and storage temperature on postharvest diseases and physiology of carrots (Daucuscarota L.). J. Am. Soc. Hortic. Sci., 119: 563-597.

Marr, K.A. 2004. Invasive Candida infections: the changing epidemiology. J. Oncol., 18 (14) Suppl 13. 9-14.

Mcdonough, M.X., Campabadal, C.A., Mason, L.J., Maier, D.E., Denvir, A. and Woloshuk, C. 2011. Ozone application in a modified screw conveyor to treat grain for insect pests, fungal contaminants, and mycotoxins. J. Stored Prod. Res. 47, 249254.

McDowell, R.E., Wilk, J.C., Shah, S.K., Balain, D.S. and Metry, G.H. 1995.Potential for commercial dairying with buffaloes. North Carolina State University, USA.

Mogda, k. Mansour; Hassan, A.A. and Rashed M.A. 2002. The fungi recorded in imported feed samples with reference to control of T-2 toxicosis by antioxidant substances in chicks. Vet. Med. J., Giza, 50(4): 485-499.

Mosherf, B.S.2005. Studies causes of inastitis in buffaloes. Ph.D. thesis of Fac. Vet. Med. Cairouniv. Egypt.

Nabawy, Gehan A., Hassan, A. A., El- Ahl, Rasha, H. S. and Refai, M. K. 2014.Effect of metal nanoparticles in comparison with Commercial antifungal feed additives on the growth of Aspergillusflavus and aflatoxin b1 production. J. Global Biosci., Volume 3, Number 6, 2014, pp. 954-971.

Najafi, M. and Khodaparast, H. 2009. Efficacy of ozone to reduce microbial populations in date fruits. Food Control, 20:27-30.

Nakashima, T., Nozawa, A. and Majima, T. 2002. A novel method using micropig stratumcorneum in vitro for the evaluation of anti-Trichophytonmentagrophytes activity Pharmaceutical R \& D Laboratories, Pola Chemical Industries, Inc. Yokohama, Kamagawa 244.0812, Japan.

Neil, S. R., Sonja, W. and Ingrid L. 1998. Invitro activities of trbinofine against cutaneous isolates of $C$. albicansand other pathogenic yeast. Am. Soc. J. 
Microbial.42:(5. 1057-1061

Okeke, C.N., Tsuboi, R., Kawai, M. and Ogawa, H. 2000. Fluorometric assessment of in vitro antidermatophytic activities of antimycotics based on their keratinpenetrating power. Am. Soc. J. Microbiol. 38 (2. 489-491.

Palli D, Sera F, Giovannelli L, Masala G, Grechi D, Bendinelli B, Caini S, Dolara P, Saieva C (2009) Environmental ozone exposure and oxidative DNA damage in adult residents of florence, Italy. Environ Pollut., 157:1521-1525.

Palmer, G. E. 2008.Autophagy in Candida albicans. J. Methods Enzymol., 451: 31122.

Philpot, W.N. and Nickerson, S.C. 1999.Mastitis: Counter Attack. West falia Surge LLC: Illinois, USA.

Pitt, J.I., and Hocking, A.D. 2009. Fungi and food spoilage. Springer Science \& Business Media press.

Radwan, M. 2008. Characterization of Candidaalbicans Strains by Biochemical and Molecular Biology Techniques Bull. Fac. Pharm. Cairo Univ., Vol. 46, No. 1 (Special Issue).

Refai, M. K. 1979. Manual of food quality. 4. Microbiological analysis. Food and Agriculture organization of United Nations, Rome. FAO, P.P. Fz\& 5 D 32.

Refai, M., Heidy Abo El-Yazid and El-Hariri, M. 2014a. Monograph On Dermatophytes: A guide for isolation and identification of dermatophytes, diseases and treatment. https://www.academia.edu.eg.

Refai, M.K. and Hassan, A.A. 2013. Monograph OnMycotoxigenic Fungi and Mycotoxins in food and feeds with synopsis of the authors done on Mycotoxigenic Fungi and Mycotoxins in Foods and Feeds. https://www.academia.edu.eg./ Egypt, Mohamed Refai/ Monograph.

Refai, M.K., Mona El- Enbawy and Hassan, A A., 2014 b. Monograph On Candida albicans.(https://www.academia.edu.eg./7 688721).AtefHassan(https://www.researc hgate.net/publication/AtefHassan).

Sayed El Ahl, Rasha, H., Hassan, A.A., El Barawy, A.M.R.T. Salem W.M.
Tawakkol, H.A. Abdel- Lateif and Refai, M.K. 2006. Prevalence of fungi and toxigenicity of A.flavus and A.ochraceus isolates recovered from feed and their control. Egyp. J. Agric. Reas., 84 (4),1303-1318.

Savi, G.D., Piacentini, K., Bittencourt, K.O. and Scussel, V.M. 2014a. Ozone treatment efficiency on $F$. graminearum \& deoxynivalenol degradation and its effects on whole wheat grains (Triticumaestivum L.) quality and germination. J. Stored Prod. Res., doi: 10.1016/j.jspr.2014.03.008.

Savi, G.D., Piacentini, K., Bittencourt, K.O. and Scussel, V.M. 2014 b. Ozone treatment efficiency in Aspergillus\&Penicillium growth inhibition and mycotoxin degradation of stored wheat grains (Triticumaestivum L.). J. Food Process Pres.

Scussel, V.M. 2005. Fungosemgrãosarmazenados. In Qualidade de arroznapós-colheita (I. Lorini and M.C. Elias, eds.) p. 79, UFPEL, Abrapós, Pelotas, RS.

Scussel, V.M., Beber, M. and Tonon, K.M. 2011b. Efeitos da infecçãoporFusarium/Gibberellanaqualida de e segurança de grãos, farinhas e produtosderivados. In Semináriosobregiberelaemcereais de inverno, 1st Ed. E.M. Reis, ed.) pp. 131175, Berthier, Passo Fundo.

Scussel, V.M, Giordano, B.N., Simao, V., Manfio, D., Galvano, S. and Rodrigues, M.N.F. 2011a. Effect of oxygen-reducing atmospheres on the safety of packaged shelled Brazil Nuts during storage. Int. J. Anal. Chem. 2011, 1-9.

Scussel, V.M, Savi, G.D. and Beber, M.. 2012. Micotoxinasemarroz e seusprodutos. In Qualidade de arroz da póscolheitaaoconsumo, 1st Ed., Vol. 1 (M.C. Elias, M. Oliveira and N.L. Vanier, eds.) pp. 115-138, Universitária da UFPEL, Pelotas.

ShawkyNahed, M.A., A.A. Hassan; Rasha M.H. Sayed El Ahl, and H.H. Mahmoud, 2014. Evaluation of the antimicrobial effect of zinc oxide nanoparticles on Listeria 
monocytogenes and Candida albicans isolated from infected Egyptian buffalo suffering from abortion. 2nd Scientific Conference of Scientific Ass. of An. Health Res., 2-4: 110-119.

Sheehan, D.J., Christopher, A.H. and Carol, M.S. 1999.Current and Emerging Azole Antifungal Agents. Clin. Microbiol. Rev., 12(1): 40-79.

SPSS 14. 2006. Statistical Package for Social Science, SPSS for windows Release 14.0.0, 12 June, 2006." Standard Version, Copyright SPSS Inc., 1989-2006, All Rights Reserved, Copyright R SPSS Inc.

Tiwari, B.K., Brennan C.S,. Curran, T., Gallagher, E., Cullen, P.J., et al. 2010. Application of ozone in grain processing.
J. Cereal Sci., 51: 248-255.

Todar, K. 2009. The control of microbial growth, PhD University of WisconsinMadison, Department of Bacteriology.

Yuan-Yuan Chen, Zheng-TaoYang, Wen-Bo Liu, Qiao-Cheng Chang, Li-Guo Wang and Nai-Sheng Zhang. 2012. Prevalence and Major Pathogen Causes of Dairy Cows Subclinical Mastitis in Northeast China. J. Animal and Vet. Adv., 11: 12781280.

Zorlugenc, B., Kırog, F., Zorlugenç, L., Ztekin, S. and Evliya, B. 2008. The influence of gaseous ozone and ozonated water on microbial flora and degradation of aflatoxin B1 in dried figs. Food and Chem. Toxicol., 46: 3593-3597.

\section{How to cite this article:}

Hassan A. Atef, Nahed, M. El-Mokhttar and Hanaa M. Abdel Khalek. 2016. Comparative Effect of Ozone and Traditional Antimycotic Drugs on the Growth of Some Fungal Causes of Recurrent Mastitis in Egyptian Buffaloes. Int.J.Curr.Microbiol.App.Sci. 5(12): 819-834. doi: http://dx.doi.org/10.20546/ijcmas.2016.512.091 